\title{
H2-antagonist in lgE-mediated type I hypersensitivity reactions: what literature says so far?
}

\author{
Matteo Borro ${ }^{1,2,3^{*}} \mathbb{D}$, Simone Negrini ${ }^{1}$, Andrew Long ${ }^{2}$, Sharon Chinthrajah ${ }^{2}$ and Giuseppe Murdaca ${ }^{1}$
}

\begin{abstract}
Histamine is a monoamine synthesized from the amino acid histidine that is well-known for its role in lgE-mediated anaphylaxis but has shown pleiotropic effects on the immune system, especially in order to promote inflammatory responses. $\mathrm{H}_{1}$-receptor antagonist are common drugs used in mild/moderate allergic reactions whereas $\mathrm{H}_{2}$-receptor antagonist are commonly administered in gastric ulcer but showed some properties in allergy too. The EAACl guidelines for diagnosis and treatment of anaphylactic reactions recommend their use as third-line therapy in adjunct to $\mathrm{H}_{1}$-antagonists. The purpose of this article is to produce a complete summary of findings and evidence known so far about the usefulness of $\mathrm{H}_{2}$-receptor antagonist in allergic reactons.
\end{abstract}

Keywords: $\mathrm{H}_{2}$-receptor antagonist, Histamine, Type-I hypersensitivity reaction, Allergy

To the editor,

According to EAACI guidelines for diagnosis and treatment of anaphylactic reactions [1], $\mathrm{H}_{2}$ anti-histamines are recommended as third-line therapy in adjunct to $\mathrm{H}_{1}$-antagonists. A recent systematic review evaluating acute and long-term management options for anaphylaxis concluded that this combination may require additional research prior to being included in recommended guidelines [2]. Histamine is a well-known immunomodulatory molecule that is able to influence the Th1/Th2 balance through a number of mechanisms and receptors [3, 4]. Among CD4+ T lymphocytes, Th1 cells are known to express higher levels of $\mathrm{H}_{1}$-receptor in contrast to Th2 cells that express a significantly greater proportion of $\mathrm{H}_{2}$-receptors. Through the binding of H1-receptor, histamine is able to activate a Th1-characterized response by increasing the release of interferony. Alternatively, through $\mathrm{H}_{2}$-receptor, histamine is able to suppress a Th1

\footnotetext{
*Correspondence: borromatteo@libero.it

${ }^{1}$ Clinical Immunology Unit, Department of Internal Medicine, University of Genoa and Ospedale Policlinico San Martino, 16132 Genoa, Italy Full list of author information is available at the end of the article
}

and/or Th2 response [5] by inhibition of IL-2, IL-4, IL-13, and interferony production [6]. Within dendritic cells, histamine can drive an increase in expression of both MCH-II and the co-stimulatory molecules CD80 and CD86. Binding at the $\mathrm{H}_{2}$ receptor on both dendritic cells and monocytes, it can induce the production of IL-10, and, specific to monocytes, downregulate the release of IL-12, thus shifting the Th1/Th2 balance toward Th2dominance [7]. Within eosinophilic granulocytes, histamine presents contrasting effects: low concentrations induce an increase in chemotaxis through $\mathrm{H}_{4}$-receptors, whereas greater concentrations are responsible for decreased chemotaxis via $\mathrm{H}_{2}$-receptors [6].

Despite their use in IgE-mediated reactions, especially in urticaria, $\mathrm{H}_{2}$-antagonists have only been documented to reduce wheal, flare, and itching sensation during skin prick test (SPT) procedures [8] and to improve cutaneous symptoms in small studies when administered in conjunction with $\mathrm{H}_{1}$-antagonists [9-11]. In an early study evaluating the use of anti-histamines in a mouse model of peanut-induced anaphylaxis, the co-administration of an $\mathrm{H}_{1}$ - and $\mathrm{H}_{2}$-antagonist failed to demonstrate any 
improvement in the severity nor course of the anaphylactic reaction [12]. Findings from a recent retrospective study in humans have demonstrated that, when used alone, $\mathrm{H}_{2}$-antagonists appear unable to inhibit reactions associated with a histamine control during a SPT. Only when administered in conjunction with additional medications possessing anti-histamine properties the $\mathrm{H}_{2}$-antagonists demonstrate increased efficacy in suppression of histamine control-induced SPT reactions, likely due to the effects of the additional medications [13]. Research by Fedorowicz et al. are in agreement with these findings, concluding that the evidence supporting the use of $\mathrm{H}_{2}$-antagonists in the treatment of urticaria is weak and unreliable [14]. In addition, a small randomized, double-blind, placebo-controlled study suggested that the combination of cetirizine and ranitidine was not more effective than cetirizine alone in the treatment of chronic urticaria [15]. These findings are in contrast to a recent study specifically evaluating cholinergic urticaria suggesting that addition of an $\mathrm{H}_{2}$-antagonist (e.g. lafutidine) to ongoing $\mathrm{H}_{1}$-antagonist therapy could significantly reduce both objective and subjective symptoms and improve the patient's quality of life [16]. This finding agrees with a previous retrospective cohort study that evaluated the efficacy and usefulness of adding lafutidine as an adjunct therapy in patients with idiopathic chronic urticaria that was not sufficiently controlled by an $\mathrm{H}_{1}$-antagonist alone. $74 \%$ of patients considered lafutidine as useful or better after 3 months of treatment [17]. However, it should be noted that cholinergic urticaria is not solely an IgE-mediated disease, but can involve a complex pathogenesis including cholinergic stimuli, histamine-release, type-I hypersensitivity reactions to sweat and Malassezia globose, and poral occlusion [18].

Cimetidine, the first $\mathrm{H}_{2}$-antagonist introduced into clinical practice, has been shown to reduce the suppressor activity of Foxp3 + CD $4+C D 25+$ Treg cells through an increased degradation of Foxp3 [19]. Additional research has linked the use of cimetidine to an increase in Th1-type cytokine-mediated immune responses and delayed-type hypersensitivity reactions [20]. In a study involving mice sensitized with a ovalbumin, the administration of cimetidine resulted in a significant increase in both specific-IgE and IL-5 levels in the culture supernatants of spleen cells, whereas Th1-, Th2-, and Th17-type cytokines did not differ between treated and untreated mice [21]. Similar results were found in a mouse model of allergic rhinitis in which the mice were sensitized to ovalbumin: the group treated with ranitidine, an $\mathrm{H}_{2}$-antagonist, in conjunction with ovalbumin immunotherapy demonstrated higher levels of specificIgE and IL-13 in their nasal lavage fluid, as well as greater levels of eosinophils in their nasal mucosa tissue, when compared to the untreated control group, suggesting a pro-inflammatory effect of the $\mathrm{H}_{2}$-antagonist on specific immunotherapy [22]. In studies of humans, cimetidine has demonstrated additional pro-inflammatory effects including the increased release of Th1-type cytokines, in particular IL-12 and IL-2 [23-25]. Pastorello et al. evaluated sixty-seven patients with systemic allergic reactions to amoxicillin, ranging from mild to severe, and, surprisingly, they found that treatment with an $\mathrm{H}_{2}$-antagonist was significantly related to severe reactions $(\mathrm{p}=0.007)$ [26]. In monocytes and dendritic cells, the administration of ranitidine was associated with a reduction in histamine-associated suppression of IL-12 release via the $\mathrm{H}_{2}$ receptor [7, 27]. In addition to monocytes and dendritic cells, $\mathrm{H}_{2}$-receptor effects were evaluated in basophils collected from patients undergoing venom immunotherapy. Interestingly, the authors detected a rapid upregulation of $\mathrm{H}_{2}$-receptor and strong suppression of FceRI-induced basophil activation and mediator release, including histamine and sulfidoleukotrienes, within the first $6 \mathrm{~h}$ of the build-up phase [28].

The majority of these findings appear to suggest that $\mathrm{H}_{2}$-antagonists may illicit pro-inflammatory effects, or effects that work in opposition to allergen immunotherapy; however, in 2016, Lee et al. demonstrated that roxatidine presents anti-allergic and tolerogenic effects through the inhibition of NF- $\mathrm{kB}$, a transcription factor involved in immune regulation, apoptosis, cell differentiation, inflammation, and cancer [29]. In particular, roxatidine was able to suppress the release of inflammatory cytokines such as TNF- $\alpha$, IL- 6 , and IL- $1 \beta$ from mast cells and delay the fatality rate in anaphylactic-induced mice. Moreover, the authors found that roxatidine significantly reduced ear swelling, mast cell accumulation, cytokine levels, and dendritic cell migration in sections of ear tissue in an animal model of allergen-induced contact hypersensitivity [30]. Additional findings by Geng et al. further support the anti-inflammatory effects of $\mathrm{H}_{2}$-antagonists, demonstrating that both systemic corticosteroids and $\mathrm{H}_{2}$-antagonists are associated with a significantly greater odds ratio for a negative outcome to the histamine control during SPT [31].

As summarized in Table 1, the scientific evidence supporting the role of $\mathrm{H} 2$-antagonists in the treatment of allergic reaction remains conflicted. It is possible that $\mathrm{H}_{2}$-antagonists may exert their effects more rapidly on $\mathrm{H}_{2}$-receptors located in vessels and on smooth muscles compared to those on immune-cells [16]. Alternatively, when administered as an adjunct to an $\mathrm{H}_{1}$-antagonist, it is feasible that they could increase the circulating blood levels via interference in drug metabolism and clearance [32]. Further investigations into the use of $\mathrm{H}_{2}$-antagonists during ongoing immunotherapy are 
Table 1 Summary of the research manuscripts assessing the role of $\mathrm{H} 2$-antagonist in IgE-mediated type I hypersensitivity reactions

\begin{tabular}{llll}
\hline Article & Animal/human Study & Molecule analyzed & Other therapy (adj \\
\hline Kupczyk et al. [8] & In vivo human study & Ranitidine & \\
Runge et al. [9] & In vivo human study & Cimetidine & Diphenhydramine \\
Lin et al. [10] & In vivo human study & Ranitidine & Diphenhydramine
\end{tabular}

Dhanya et al. [11]

In vivo human study

Ranitidine

Levocetirizine

Arias et al. [12]

In vivo mouse study

Cimetidine

Mepyramine

Shah et al. [13]

In vivo human study

Famotidine

Ranitidine

Cimetidine

Fedorowicz et al. [14]

Review on human studies

Ranitidine

Cimetidine

Guevara-Gutierrez et al. [15] In vivo human study

Hatakeyama et al. [16]

In vivo human study
Lafutidine
Ranitidine

Cetirizine

Cetirizine

Fexofenadine

Bepotastine

Ebastine

Olopatadine

Levocetirizine
Results

Ranitidine was able to suppress the wheal, flare, and itching sensation in SPT

In acute urticaria, cimetidine + diphenhydramine is more effective than diphenhydramine alone.

The addition of ranitidine to diphenhydramine results in improvement of cutaneous manifestations in patients with acute allergic syndromes

Levocetirizine + ranitidine resulted in significant reduction of wheal size at 2, 3, 6, and $24 \mathrm{~h}$ vs. levocetirizine alone.

The co-administration of $\mathrm{H}_{1}$ and $\mathrm{H}_{2}$-antagonist had no impact on the severity or the course of anaphylactic reaction

$\mathrm{H}_{2}$-antagonists had no effect on the positive histamine skin test; if associated with other potentially antihistaminic medications, the odds of a negative histamine control increased. Authors concluded that a 0-2-day discontinuation before testing is recommended.

Evidence for the effectiveness of $\mathrm{H}_{2}$-antagonist in urticaria is limited, weak and unreliable. Based on the review, there is not enough evidence to answer the question of whether $\mathrm{H}_{1}-+$ $\mathrm{H}_{2}$-antagonists are better than just $\mathrm{H}_{1}$ - antagonists alone.

Combination therapy with cetirizine and ranitidine was not more effective than cetirizine alone in chronic urticaria.

Authors concluded that lafutidine can be recommended as an adjunct therapy that improved disease activity and QoL in patients with refractory cholinergic urticaria. 
Table 1 (continued)

\begin{tabular}{llll}
\hline Article & Animal/human Study & Molecule analyzed & Other therapy (adjunct) \\
\hline Ogawa et al. [17] & In vivo human study & Lafutidine & $H_{1}$-antagonists (not speci- \\
fied)
\end{tabular}

Results

Zhang et al. [19]

In vitro human study

Cimetidine

Avella et al. [20]

In vivo human study

Cimetidine

Arae et al. [21]

Shin et al. [22]

In vivo mouse model

Ranitidine

Ishikura et al. [23]

Hahm et al. [24]

In vitro human study

Cimetidine Ranitidine

Famotidine

Jafarzadeh et al. [25]
In vivo mouse model
Cimetidine
In idiopathic chronic urticaria, lafutidine as adjuvant therapy showed a moderate improvement or better in 85 and $76 \%$ of patients after $1-$ 3 weeks and after 3 months, respectively. Lafutidine was rated as useful or better in $74 \%$ of evaluated patients after 3 months of treatment.

Cimetidine suppresses the function of Treg cells through a reduction of Foxp3 via E3 ligase Stub1mediated proteosomal degradation.

Cimetidine therapy prevented a natural decline in delayed hypersensitivity skin tests to four common antigens and significantly increased delayed hypersensitivity, measured by the degree of erythema at both 24 and $48 \mathrm{~h}$ and induration at $48 \mathrm{~h}$.

Administration of cimetidine to Ovalbumin-sensitized $\mathrm{BALB} / \mathrm{C}$ mice increased serum level of Ovalbuminspecific $\lg \mathrm{E}_{1} \lg \mathrm{G}_{1}$ and $\lg \mathrm{G}_{2 a}$ In vitro analysis showed an increased IL-5 secretion by Ovalbumin-stimulated spleen cells.

Treatment with ovalbumin immunotherapy + ranitidine showed a significant increase in serum specific IgE levels, nasal lavage fluid IL-13 levels and the number of tissue eosinophils when compared both with immunotherapy alone and with immunotherapy $+\mathrm{H}_{2}$-agonist.

Cimetidine significantly increases serum IL-12 levels in patient admitted to the intensive care unit

In peripheral blood mononuclear cells from patients with gastric cancer, cimetidine increases the cytotoxicity and proliferative response of lymphocyte to mitogen

In a mouse model, cimetidine significantly increased both serum levels of IL-2, IL-10, IL-12, and IL-17 and delayed type hypersensitivity responses that are normally suppressed after a burn injury. 
Table 1 (continued)

\begin{tabular}{lll}
\hline Article & Animal/human Study & Molecule analyzed \\
\hline Pastorello et al. [26] & In vivo human study & $\begin{array}{c}\mathrm{H}_{2} \text {-antagonists (not speci- } \\
\text { fied) }\end{array}$
\end{tabular}

Other therapy (adjunct) Results

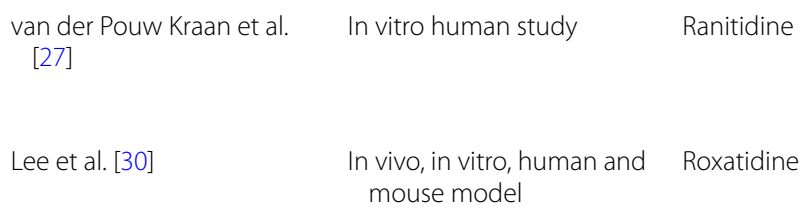

Therapy with $\mathrm{H}_{2}$-antagonists
was significantly associ-
ated with an increase in the
risk of a severe reaction to
amoxicillin. Patients that
had received $\mathrm{H}_{2}$-antagonists
presented higher levels of
specific lgE.
In human monocytes, raniti-
dine reversed the inhibition
of IL-12 production caused
by histamine.
Roxatidine suppressed both
the expression of TNF-a, IL-6,
and IL-1 3 , and the activation
of caspase-1, in stimulated
human mast cells and in
anaphylactic mouse model.
In animal model of allergen-
induced contact hypersensi-
tivity, roxatidine significantly
reduced ear swelling, mast
cell accumulation, cytokine
levels, and dendritic cell
migration in sections of ear
tissue.
The administration of
${ }_{2}$-antagonists is associated
with a significant odds ratio
for a negative histamine
response at prick test.
Hydroxyzine + cimetidine
showed a significant
increase both in serum
hydroxyzine concentrations
and in suppression of the
histamine-induced wheal
and flare.

$\mathrm{H}_{2}$-antagonists (not specified) and flare. needed to evaluate their use in the treatment or prevention of IgE-mediated allergic reactions.

\section{Abbreviations}

SPT: Skin prick test.

\section{Acknowledgements}

Not Applicable.

\section{Authors' contributions}

MB wrote the manuscript, GM collected all the materials, SN reviewed the structure of the article, AL verified for grammar errors, SC designed the article. All authors read and approved the final manuscript.

\section{Funding}

No funding.

\section{Declarations}

Ethics approval and consent to participate

Not applicable.

\section{Consent for publication}

Not applicable.

\section{Competing interests}

The authors declare that they have no competing interests.

\section{Author details}

${ }^{1}$ Clinical Immunology Unit, Department of Internal Medicine, University of Genoa and Ospedale Policlinico San Martino, 16132 Genoa, Italy. ${ }^{2}$ Sean N. Parker Center for Allergy and Asthma Research at Stanford University, Stanford University, Grant Building, S093, 300 Pasteur Dr., Stanford, CA 94305-5101, USA. ${ }_{3}^{3}$ Department of Internal Medicine, San Paolo Hospital, Via Genova 30 -, 17100, Savona, Italy.

Availability of data and materials

Not applicable. 
Received: 19 February 2021 Accepted: 27 March 2021

Published online: 13 April 2021

\section{References}

1. Muraro A, Roberts G, Worm M, Bilo MB, Brockow K, Fernandez Rivas M, et al. Anaphylaxis: guidelines from the European academy of allergy and clinical immunology. Allergy. 2014;69(8):1026-45.

2. Dhami S, Sheikh A, Muraro A, Roberts G, Halken S, Fernandez Rivas M, et al. Quality indicators for the acute and long-term management of anaphylaxis: a systematic review. Clin Transl Allergy. 2017;7:15.

3. Packard KA, Khan MM. Effects of histamine on Th1/Th2 cytokine balance. Int Immunopharmacol. 2003;3(7):909-20.

4. Ahmad SF, Zoheir KM, Ansari MA, Korashy HM, Bakheet SA, Ashour AE, et al. Stimulation of the histamine 4 receptor with 4-methylhistamine modulates the effects of chronic stress on the Th1/Th2 cytokine balance. Immunobiology. 2015;220(3):341-9.

5. Baumer W, Rossbach K. [Histamine as an immunomodulator]. J Dtsch Dermatol Ges. 2010;8(7):495-504.

6. Thurmond RL, Gelfand EW, Dunford PJ. The role of histamine $\mathrm{H} 1$ and $\mathrm{H} 4$ receptors in allergic inflammation: the search for new antihistamines. Nat Rev Drug Discov. 2008;7(1):41-53.

7. Elenkov IJ, Webster E, Papanicolaou DA, Fleisher TA, Chrousos GP, Wilder RL. Histamine potently suppresses human IL-12 and stimulates IL-10 production via H2 receptors. J Immunol. 1998;161 (5):2586-93.

8. Kupczyk M, Kuprys I, Bochenska-Marciniak M, Gorski P, Kuna P. Ranitidine (150mg daily) inhibits wheal, flare, and itching reactions in skin-prick tests. Allergy Asthma Proc. 2007;28(6):711-5.

9. Runge JW, Martinez JC, Caravati EM, Williamson SG, Hartsell SC. Histamine antagonists in the treatment of acute allergic reactions. Ann Emerg Med. 1992;21(3):237-42.

10. Lin RY, Curry A, Pesola GR, Knight RJ, Lee HS, Bakalchuk L, et al. Improved outcomes in patients with acute allergic syndromes who are treated with combined $\mathrm{H} 1$ and $\mathrm{H} 2$ antagonists. Ann Emerg Med. 2000:36(5):462-8.

11. Dhanya NB, Rai R, Srinivas CR. Histamine 2 blocker potentiates the effects of histamine 1 blocker in suppressing histamine-induced wheal. Indian J Dermatol Venereol Leprol. 2008;74(5):475-7.

12. Arias K, Baig M, Colangelo M, Chu D, Walker T, Goncharova S, et al. Concurrent blockade of platelet-activating factor and histamine prevents life-threatening peanut-induced anaphylactic reactions. J Allergy Clin Immunol. 2009:124(2):307-14. 14 e1-2.

13. Shah KM, Rank MA, Dave SA, Oslie CL, Butterfield JH. Predicting which medication classes interfere with allergy skin testing. Allergy Asthma Proc. 2010;31(6):477-82.

14. Fedorowicz Z, van Zuuren EJ, Hu N. Histamine H2-receptor antagonists for urticaria. Cochrane Database Syst Rev. 2012;3:8596.

15. Guevara-Gutierrez E, Bonilla-Lopez S, Hernandez-Arana S, Tlacuilo-Parra A. Safety and efficacy of cetirizine versus cetirizine plus ranitidine in chronic urticaria: Double-blind randomized placebo-controlled study. J Dermatolog Treat. 2015;26(6):548-50

16. Hatakeyama M, Fukunaga A, Washio K, Ogura K, Yamada Y, Horikawa T, et al. Addition of lafutidine can improve disease activity and lead to better quality of life in refractory cholinergic urticaria unresponsive to histamine $\mathrm{H} 1$ antagonists. J Dermatol Sci. 2016;82(2):137-9.

17. Ogawa Y, Ichinokawa Y, Hiruma M, Machida Y, Funakushi N, Sadamasa $\mathrm{H}$, et al. Retrospective cohort study on combination therapy with the histamine $\mathrm{H} 2$-receptor antagonist lafutidine for antihistamine-resistant chronic urticaria. J Dermatolog Treat. 2013;24(6):463-5.

18. Fukunaga A, Washio K, Hatakeyama M, Oda Y, Ogura K, Horikawa T, et al. Cholinergic urticaria: epidemiology, physiopathology, new categorization, and management. Clin Auton Res. 2018;28(1):103-13.

19. Zhang Y, Chen Z, Luo X, Wu B, Li B, Wang B. Cimetidine down-regulates stability of Foxp3 protein via Stub1 in Treg cells. Hum Vaccin Immunother. 2016;12(10):2512-8

20. Avella J, Madsen JE, Binder HJ, Askenase PW. Effect of histamine $\mathrm{H} 2$-receptor antagonists on delayed hypersensitivity. Lancet. 1978;1 (8065):624-6.

21. Arae K, Oboki K, Ohno T, Hirata M, Nakae S, Taguchi H, et al. Cimetidine enhances antigen-specific IgE and Th2 cytokine production. Allergol Int. 2011;60(3):339-44.

22. Shin JH, Kim BG, Kim SW, Cho JH, Park YJ, Kim SW. Immunomodulatory role of histamine $\mathrm{H} 2$ receptor in allergen-specific immunotherapy: a mouse model of allergic rhinitis. Otolaryngol Head Neck Surg. 2011:144(4):500-5.

23. Ishikura H, Fukui $H$, Takeyama N, Tanaka T. Cimetidine activates interleukin-12, which enhances cellular immunity. Blood. 1999:93(5):1782-3.

24. Hahm KB, Kim WH, Lee SI, Kang JK, Park IS. Comparison of immunomodulative effects of the histamine-2 receptor antagonists cimetidine, ranitidine, and famotidine on peripheral blood mononuclear cells in gastric cancer patients. Scand J Gastroenterol. 1995;30(3):265-71.

25. Jafarzadeh A, Nemati M, Rezayati MT, Ebrahimi M, Hassan ZM. Cimetidine enhances delayed-type hypersensitivity responses and serum interleukin (IL)-2, -10, -12, and IL-17 levels after burn injury in an animal model. J Immunotoxicol. 2013;10(2):201-9.

26. Pastorello EA, Stafylaraki C, Mirone C, Preziosi D, Aversano MG, Mascheri A, et al. Anti-amoxicillin immunoglobulin E, Histamine-2 receptor antagonist therapy and mast cell activation syndrome are risk factors for amoxicillin anaphylaxis. Int Arch Allergy Immunol. 2015;166(4):280-6.

27. van der Pouw Kraan TC, Snijders A, Boeije LC, de Groot ER, Alewijnse AE, Leurs R, et al. Histamine inhibits the production of interleukin-12 through interaction with H2 receptors. J Clin Invest. 1998;102(10):1866-73.

28. Novak N, Mete N, Bussmann C, Maintz L, Bieber T, Akdis M, et al. Early suppression of basophil activation during allergen-specific immunotherapy by histamine receptor 2. J Allergy Clin Immunol. 2012;130(5):1153-8 e2.

29. Baud V, Karin M. Signal transduction by tumor necrosis factor and its relatives. Trends Cell Biol. 2001;11(9):372-7.

30. Lee M, Lee NY, Chung KS, Cheon SY, Lee KT, An HJ. Roxatidine attenuates mast cell-mediated allergic inflammation via inhibition of NF-kappaB and p38 MAPK activation. Sci Rep. 2017;7:41721.

31. Geng B, Thakor A, Clayton E, Finkas L, Riedl MA. Factors associated with negative histamine control for penicillin allergy skin testing in the inpatient setting. Ann Allergy Asthma Immunol. 2015;115(1):33-8.

32. Simons FE, Sussman GL, Simons KJ. Effect of the H2-antagonist cimetidine on the pharmacokinetics and pharmacodynamics of the $\mathrm{H} 1$-antagonists hydroxyzine and cetirizine in patients with chronic urticaria. J Allergy Clin Immunol. 1995;95(3):685-93.

\section{Publisher's note}

Springer Nature remains neutral with regard to jurisdictional claims in published maps and institutional affiliations. 